\title{
"To Save Succeeding Generations from the Scourge of War": Jan Smuts and the Ideological Foundations of the United Nations
}

\author{
Christof Heyns* \& Willem Gravett**
}

\begin{abstract}
The story of the founding of the United Nations reflects its complicated ideological foundations. Jan Smuts, who wrote the words "human rights" into the Charter, was also the premier of white-ruled South Africa. Smuts embodies the dualism that runs through international law itself: the pursuit of the common good is invariably tied to its own interest. It was only through the interventions of the emerging global community, and in particular the developing world-and consequently the repudiation of Smuts and the apartheid policies of his successors - that human rights attained a more universal nature. Human rights have deeper, but also darker, roots than many current accounts would have it.
\end{abstract}

\section{INTRODUCTION}

An under-explored case study in understanding the complex foundations of human rights and international law is the visionary and controversial South African, Jan Christian Smuts. A principal author of the Covenant of the League of Nations, and the person directly responsible for the recognition

\footnotetext{
* Christof Heyns is Professor of Human Rights Law and Director of the Institute for International and Comparative Law in Africa, Faculty of Law, University of Pretoria.

** Willem Gravett is a Senior Lecturer, Faculty of Law, University of Pretoria.

We would like to thank Saul Dubow, John Dugard, Christopher McCrudden, Bill Schwarz, and Richard Steyn for comments on earlier drafts. Charles Comley has been a constant source of information.
} 
of human rights as a founding value in the Charter of the United Nations, he was also the premier of white-ruled South Africa, which would become infamous under his successors as the apartheid state.

In Long Walk to Freedom, Nelson Mandela recounts how, as a young undergraduate student at Fort Hare in 1939, he attended a speech given by Smuts on the campus of the university. He found Smuts to be a generally "sympathetic figure," and supported his stance on the war against Hitler, but this did not change the fact that Smuts "had helped found the League of Nations, promoting freedom around the world" and, at the same time, was "repress[ing] freedom at home."

"I am suspected of being a hypocrite," Smuts himself wrote at a later stage, "because I can be quoted on both sides. The Preamble of the Charter is my own work, and I also mean to protect the European position in a world which is tending the other way." ${ }^{2}$

Smuts can be seen as one of the founders of the global human rights system and, at the same time, as someone with a paternalistic approach to race and someone who showed little hesitation to use force when he considered it necessary. Looking back from where we are today, it is clear that he played a leading role in the emergence of the moral opposites of the last century: human rights and racial segregation.

Until recently, many authors who cover the history of the international system have left references to Smuts largely or even completely out of the picture they present-either deliberately or because it was not covered in the sources they consulted. ${ }^{3}$ While those engaged in developing the human

1. Nelson Mandela, Long Walk to Freedom 42 (1994).

2. Smuts to M.C. Gillett 14 January 1947, see W.K. Hancock, Smuts: The Fields of Force 1919-1950, at 450 (1968).

3. For example, Smuts is mentioned only briefly with regard to his role in drafting the Preamble to the Charter in Rüdiger Wolfrum, Preamble, in The Charter of the United Nations: A Commentary 45, 45 (Brunno Simma et al. ed., 1994), while there is no reference to his contribution to the Preamble in Paul Kennedy, The Parlament of Man: The Past, Present, and Future of the United Nations (2006). Kennedy briefly mentions Smuts as one of the individuals who drafted schemes for the League of Nations. Id. at 8 . There is also no mention of Smuts' role in drafting the Preamble in Evan Luard, A History of the United Nations, Volume 1: The Years of Western Domination, 1945-1955 (1982); Roger Normand \& Sarah Zaidi, Human Rights at the UN: The Political History of Universal Justice (2008); Maurice Waters, The United Nations: International Organization and Administration (1967); Richard Jolly, Louis Emmerij \& Thomas G. Weiss, UN Ideas that Changed the World (2009); The United Nations System and Its Predecessors, Volume I: The United Nations System (Hans von Mangoldt \& Volker Rittberger eds., 1997); Bengt Broms, The United Nations (1990); Hurst Hannum, Human Rights, in The United Nations and International Law 131 (Christopher C. Joyner ed.,1997); Leland Goodrich, From League of Nations to United Nations, 1 INT'L. Org. 3 (1947); Kenneth Cmiel, The Recent History of Human Rights, 109 Am. Hist. Rev. 117 (2004); Jean Krasno, A Step Along an Evolutionary Path: The Founding of the United Nations, 2 Global Dialogue 9 (2000); E.J. Hughes, Winston Churchill and the Formation of the United Nations Organization, 9 J. Contemporary Hist. 177 (1974). 
rights project may initially — and perhaps understandably — not have been eager to emphasize the complexities of its genealogy, presenting a sanitized history is bound in the long run to lead to shortcomings in the understanding of the way human rights evolved-and, in our view, in understanding its complexity but also its resilience.

The literature about "the end of human rights" has proliferated. ${ }^{4}$ Some contemporary historians, such as Samuel Moyn, ${ }^{5}$ discard an evolutionary understanding of human rights, and advance an approach that sees the history of human rights as largely discontinuous, and, consequently, regard its long term effects as transient. Moyn also claims that the emergence of human rights in the founding of the UN had little or nothing to do with the Holocaust. ${ }^{6}$ Moyn locates the origins of the international human rights movement in the 1970s, because it was only then that "they were widely understood as a moral alternative to bankrupt political utopias," such as socialism, nationalism, and communism. ${ }^{7}$ Christopher McCrudden points out that the "radical discontinuity" approach of Moyn and other revisionists fails to convincingly account for the normativity of human rights. ${ }^{8}$

As exemplified by Smuts' story, one of the reasons why human rights are seen as a transient phenomenon may be that human rights have a longer-and a more complicated and in some ways troubling-history than traditional accounts reveal. ${ }^{9}$ Troubling as a reflection on the role of Smuts might be, it is a reality which in one way or another has to be faced if the human rights project is to be subjected to full and critical scrutiny.

It is our contention that, if a date has to be set for the origins of the modern concept of human rights-which places the protection of the core interests of the individual at the center and establishes a formal regime of remedies for infringements—-the year 1945 has much to offer as a contender.

4. See, e.g., Eric A. Posner, The Twilight of Human Rights Law (2014); Stephen Hopgood, The Endtimes of Human Rights (2013); Makau Mutua, Is the Age of Human Rights Over?, in The Routledge Companion to Literature and Human Rights 450 (Sophia A. McClennen \& Alexandra Schultheis Moore eds., 2016).

5. See Christopher McCrudden, Human Rights Histories, 35 Oxford J. Legal Stud. 179 (2014).

6. Samuel Moyn, The last Utopia: Human Rights in History 47 (2012).

7. Id. at 5 .

8. McCrudden, supra note 5, at 200. The revisionists have also come under scrutiny from among others, Philip Alston, who rejects the "big bang" theory of human rights. Philip Alston, Does the Past Matter? On the Origins of Human Rights, 126 Harv. L. Rev. 2043, 2074-77 (2013).

9. It is also important in tracing this evolution even before the introduction of the term in the United Nations to move beyond the formal use of the term "human rights," and to focus on the idea that underlies the modern concept of human rights: that a core set of human values have crystallized over the centuries for which members of society can expect a systematic system of protection to be in place, if they are not as a last recourse entitled to take matters into their own hands. See Christof Heyns, A "Struggle Approach" to Human Rights, in Human Rights, Peace and Justice in Africa: A reader 15 (Christof Heyns \& Karen Stefiszyn eds., 2006). 
It was at the formation of the United Nations that human rights were placed at the core of the quest for world security, and the observance of human rights was turned into a legal requirement for all states that in the future wanted to be part of the world community. However, the year 1946, when India took the South African government to task over its domestic policies concerning Indians, may in some respects be an even more important date. That was the year, as we will see below, when the newly founded world body was used for the first time to enforce human rights - this time with Smuts in the dock, not as the author of human rights, but as a human rights transgressor. That altercation set the precedent for a process that neither Smuts nor his contemporaries from around the world probably foresaw, when human rights started to acquire a life of its own.

A number of recent studies by historians, political scientists, and others, such as Saul Dubow, Mark Mazower, Bill Schwarz, Joseph Kochanek, and Jeanne Morefield, have engaged the difficult task of what to make of Smuts' central role in shaping the foundational values of the modern world. ${ }^{10}$

In the field of international human rights law, Christof Heyns addressed Smuts' legacy in a 1995 article in a journal with a limited circulation, but beyond that reference, it remains largely unexplored in the human rights literature. ${ }^{11}$

In approaching the legacy of historical figures, much depends on one's chosen temporal starting point. When such figures are looked upon purely from a contemporary perspective, it is almost inevitable to super-impose current values on them.

Another approach is to say that it is unfair to judge the past with the wisdom of hindsight. Instead, historical figures have to be assessed, first and foremost, within the context of their time. Pursuant to this approach, the real question is how they responded to the challenges of their time, compared to their contemporaries, by the best light available to them.

Both perspectives clearly have their attractions, but choosing either also presents its own problems. Taking the view purely from the present ignores the real constraints that historical figures face and few, if any, would pass

10. See Mark Mazower, No Enchanted Palace: The End of Empire and the Ideological Origins of the United Nations (2009); Saul Dubow, Smuts, the United Nations and the Rhetoric of Race and Rights, 43 J. Contemporary Hist. 45 (2008); see also George Curry, Woodrow Wilson, Jan Smuts, and the Versailles Settlement, 66 Am. Hist. Rev. 968 (1961); BıLL Schwarz, Memories of Empire, Volume 1: The White Man's World 277-340 (2011); Joseph Kochanek, Jan Smuts: Metaphysics and the League of Nations, 39 Hist. Of Eur. IDEAs 267 (2012); Jeanne Morefield, Empires Without Imperialism: Anglo-American Decline and the Politics of Deflection 171-200 (2014).

11. See Christof Heyns, The Preamble of the United Nations Charter: The Contribution of Jan Smuts, 7 Afr. J. Int'L \& Comp. L. 329 (1995). 
the test. And, with regard to those alive today, the future will undoubtedly also reveal the contradictions of the present age. Trying to take a view purely from the temporal perspective of one's subject, on the other hand, ignores the reality that time moves on, values evolve, and history is written backwards, invariably with the aim of promoting a new vision.

The simultaneous validity of both-often contradictory-perspectives has to be acknowledged when those who build bridges between the present and a now-forgotten era are considered. There is little point in trying to locate a more "correct" or "neutral" perspective from which to judge historical figures-though it is helpful to be cognizant of one's own starting point.

On the topic of starting points: we are two South African lawyers from Afrikaans-speaking backgrounds, with a strong commitment to the human rights project, who undertake this enquiry to make sense, not only of human rights and their role in the world in which we live, but also of the history of our own society.

\section{BRIEF PERSONAL HISTORY OF SMUTS ${ }^{12}$}

Jan Christian Smuts (1870 to 1950) was born on 24 May 1870, on a farm near the hamlet of Riebeek-West near Cape Town, in what was then the Cape Colony, to a fairly well-to-do Afrikaner family. Smuts, who was tending the livestock on the farm, went to school for the first time at the age of twelve, when his older brother, who was to be the family's educated son, died. The expectation was that he would become a predikant (a pastor). At the small-town school in Riebeek-West, Smuts soon exhibited prodigious intellectual gifts.

Smuts entered Victoria College (later called the University of Stellenbosch) in 1886 at the age of sixteen. In 1891, he graduated with first class honors in literature and science. Smuts won the Ebden Scholarship to study law at Cambridge University. By this time he had turned away from becoming a preacher, and while in his later life was not seen as a conventional church-goer, he retained a deep commitment to what he saw as the essential tenets of Christianity. His rhetoric and writings would often be idealistic and lofty-a collection of his speeches would later tellingly be published as Toward a Better World. ${ }^{13}$

12. The following account draws on W.K. Hancock, Smuts: The Sanguine Years 1870-1919 (1962), see generally Hancock, Smuts: The Fields of Force, supra note 2; Sarah Gertrude Millin, General Smuts, Volume I (1936); Sarah Gertrude Millin, General Smuts, Volume II (1936); J.C. Smuts, Jan Christian Smuts (1952); F.S. Crafford, Jan Smuts: A Biography (1944); Richard Steyn, Jan Smuts: Unafraid of Greatness (2015); Antony Lentin, Makers of the Modern World: General Smuts: South Africa (2010).

13. Jan Christianan Smuts, Toward a Better World (1944). 
Smuts completed both parts of the Law Tripos examination at Cambridge simultaneously, and gained a double first-an unprecedented feat. Towards the end of his career, in 1948, Smuts was installed as chancellor of Cambridge, the first foreigner to hold the position.

Upon his return to South Africa, Smuts became the State Attorney of the Transvaal Republic at the age of twenty-eight. Soon, he found himself in the position of President Paul Kruger's right-hand man. Smuts accompanied Kruger to Bloemfontein in August 1899 to negotiate with Sir Alfred Milner, British High Commissioner for South Africa, in a last-ditch effort to avoid the war that was imminent as a result of what the Transvaal saw a British attempt to annex the gold fields of the Transvaal—what is today called "white on white colonialism." He authored a vehemently anti-British imperialist tract, A Century of Wrong, as well as, in all likelihood, the ultimatum to the British Government on 9 October 1899. Two days later, the first salvos in the South African War were fired.

The Boer forces-those of the Transvaal and the Republic of the Free State-eventually were vastly outnumbered by the British. Pretoria fell in June 1900 and Kruger went abroad. Though nominally only State Attorney, Smuts found himself in sole charge of the collapsing government of the Transvaal. Having earlier drafted an eighteen-page memorandum about the approach to be followed by the Transvaal in the war, in the second half of 1900, Smuts took to the veld as a soldier under General J. H. de la Rey. Later that year, he took command in the Western Transvaal, fighting a successful guerrilla campaign in the Gatsrand. At the end of July 1901, Smuts left the Transvaal and entered the Orange Free State, and then crossed the Orange River into the Cape Colony and campaigned there for eight months.

At the peace conference at Vereeniging in 1902, Smuts supported the view that it would be better to negotiate an orderly peace, rather than be crushed later and have harsh terms thrust upon them. Smuts was taken aside by the Commander-in-Chief of the British forces, Lord Kitchener, and told that it was likely that the Liberal Party would win the next election in Britain and that it would have a more sympathetic approach to the Boer cause. Smuts was one of the drafters of the peace treaty. In a fateful move, he redrafted a clause that would have extended the franchise to a limited group of Africans, to one that deferred a decision on the African franchise until after the introduction of self-government.

During the war, 22,000 Empire troops ${ }^{14}$ and more than 7,000 Boer soldiers died, ${ }^{15}$ as well as an estimated 18,000 to 28,000 civilians $^{16}$ and an

14. Thomas Pakenham, The Boer War 607 (1979).

15. Id.

16. Id. 
unknown number of the 107,000 Africans in concentration camps ${ }^{17}$ perished. The war devastated the young republics, and antagonism between Boer and British descendants remained for many decades a major component of political life in South Africa.

Perhaps the biggest change, as far as Smuts was concerned, was that he now understood where power in international politics lay. His direct interest to promote his understanding of Western values and aligning himself closely or exclusively with the Boer cause would not provide him with the platform he needed to pursue this course on the world stage. At the same time, the white voters of what would a few years later become the Union of South Africa — of which the Afrikaners were the majority - would be his only potential power base. The author of A Century of Wrong would have to work with the British Empire. This he would do, but at the same time he would push for the Empire to tone down its imperialist tendencies, which suffered a significant blow in the war in South Africa. Smuts would, in time, become the leading voice for the transformation of the British Empire into the British Commonwealth of Nations. ${ }^{18}$

In the aftermath of the Anglo-Boer War, self-government for the former Boer republics, and the eventual unification of South Africa, remained at the top of Smuts' agenda. In 1906, on a visit to London, Smuts met with the new Liberal British Prime Minister, Sir Henry Campbell-Bannerman, and made the case for the defeated Boer Republics to be granted self-government within the British Empire. ${ }^{19}$ Campbell-Bannerman's government acquiesced. Smuts believed that the British Empire of Rhodes, Milner, and Chamberlain had come to an end with that magnanimous gesture. This act of reconciliation on the part of Britain became the cornerstone of Smuts ${ }^{\prime}$ statecraft ${ }^{20}$ and formed the basis for his collaboration with his erstwhile enemy and his belief that self-government was not necessarily incompatible with membership of a larger world body. It was also the basis for his belief in the possibilities of peace. When his nemesis in the Anglo Boer War, Lord Milner, left the country, Smuts wrote him a message, stating "[h]istory writes the word 'Reconciliation' over all quarrels."'21

When responsible government was granted to the Transvaal in December 1906, General Louis Botha became Prime Minister, and Smuts the Colonial

17. According to Pakenham, the incomplete records give the total as 7,000 , but it probably exceeds 12,000 . The number of deaths among the approximately 50,000 Africans on the British side is not known. Id.

18. J.C. Smuts, War-time Speeches vii (1917); see also Schwarz, supra note 10, at 315.

19. J.C. Smuts, Article (1948), in Selections from the Smuts Papers, Volume VII (Jean Van der Poel ed., 1973).

20. The possible influence of this part of the country's history on the later reconciliatory approach of Nelson Mandela, Desmond Tutu, and other leaders of their generation still remains to be explored.

21. As quoted in O. Geyser, Jan Smuts and His International Contemporaries 44 (2001). 
Secretary and Minister of Education. However, the promise of still larger unity loomed in South Africa; Smuts became a driving force behind the unification of the four provinces, the Cape Colony, the Transvaal, Natal, and the Orange Free State, into the Union of South Africa in 1910.

Smuts arrived at the National Convention, where the new state would be formed, with a comprehensive draft that became the blueprint for the eventual Union Constitution. According to one of his biographers, F.S. Crafford, "the work of the convention ... ultimately amounted to little more than a gradual toning down of Smuts' original thesis." ${ }^{\prime 2}$ In accordance with his preference for greater wholes, he persuaded the other delegates to follow a unitary, as opposed to a federal, model. ${ }^{23}$ Thus, the geographical boundaries of what is today known as South Africa were established.

At the outbreak of the First World War in 1914, Botha and Smuts sided with Great Britain and the Allied powers. Almost at once, a section of the Afrikaner population, still smarting from the devastating war against Britain barely twelve years earlier, took up arms in rebellion. Botha and Smuts argued that they had to support Great Britain because it had given the Union self-government. They crushed the rebellion by force, and Smuts and Botha led the Union Defense Force into German South West Africa and conquered the territory on behalf of the Allies. In 1916, Smuts was appointed Lieutenant-General in the British Army and became the theatre commander in German East Africa.

In March 1917, Smuts travelled to England as Botha's substitute on the Imperial War Cabinet. Lloyd George prevailed upon Smuts to remain in England and to join the War Cabinet proper-the Prime Minister's inner cabinet and the supreme executive body waging war. Smuts now became known as the "Handyman of the Empire." In response to vulnerability to German air raids, Smuts recommended not only a variety of measures to protect London, but also the establishment of the Royal Air Force as an independent branch of the armed services. At Lloyd George's behest, Smuts also drafted Britain's brief for the Peace Conference. Smuts' brief stated that the aim should not be the destruction of the enemy. The Paris Peace Conference and the establishment of the League of Nations is dealt with in more detail below.

When Botha died in 1919, Smuts became Prime Minister of the Union of South Africa until his electoral defeat to General J. B. M. Hertzog in 1924. Elections among the all-white electorate were hotly contested. Smuts was

22. CRAFFord, supra note 12 , at 85 .

23. In addition to a draft constitution, Smuts prepared a memorandum outlining the main points, entitled Suggested Scheme for South African Union. See Trewhella Cameron, Jan Smuts: An Illustrated Biography 58-59 (1994). 
Leader of the Opposition in the Union Parliament until 1933, when Smuts and Hertzog merged their political parties. Smuts then served as Deputy Prime Minister under Hertzog until 1939.

Shortly after the Second World War broke out on 1 September 1939, the Prime Minister, Hertzog, introduced a motion in Parliament in favor of neutrality. Smuts moved an amendment in favor of the Union joining the Commonwealth in declaring war on Germany. Smuts carried South Africa into war by a margin of thirteen votes and became Prime Minister for a second time. Again, he faced insurrection from Afrikaners who wished to side with Germany and repressed it by force.

In the course of the war, Smuts paid nine visits to Europe and the Middle East to confer with Allied leaders. As in 1917, he was a member of the War Cabinet. In November 1943, Smuts presided over the War Cabinet for ten days during Churchill's absence (while the latter was meeting with Roosevelt and Stalin in Teheran), thus acting as the de facto Prime Minister. ${ }^{24}$ Smuts' role during the Second World War is also dealt with below.

Smuts lost the general election to the National Party in 1948, which had rallied a section of the all-white electorate behind its policy of apartheid as opposed to the milder segregationist policies of Smuts, and against his leadership that had brought South Africa into the war on the side of the Allies against Hitler. ${ }^{25}$

Smuts' nickname was "Slim (crafty) Jannie." On the one hand, this reflected the recognition of his superior intellectual abilities-by his teachers, collaborators, and foes alike. But, on the other, this was also a reference to his willingness to use these abilities to outsmart his opponents and to get his way. ${ }^{26}$ Some called him a "practical idealist," ${ }^{27}$ others said he was a "ruthless philosopher." 28

Smuts indeed had a deep interest in philosophy. During his student days at Cambridge, at the age of twenty-four and as a diversion from his law studies, Smuts wrote a thesis entitled Walt Whitman-A Study in Personality. The conclusion Smuts reached was that the determining force of life, the coordinating principle of the universe, was an impulse towards wholeness - the merging of all sub-units into a whole transcending in nature and in magnitude the constitutive parts. He called his theory "The Idea of the Whole," the forerunner of the phrase "Holism," coined from the Greek ho-

24. Papers of David Friedman, former chief editor of the South African Press Association, now available at the Smuts museum, Doornkloof, near Irene.

25. Heyns, The Preamble of the United Nations Charter, supra note 11, at 346.

26. Hancock, Smuts: The Sanguine Years, supra note 12, at 147, 167, 235, 274-77, 559; see Hancock, Smuts: The Fields of Force, supra note 2, at 5.

27. Naphtali Levi, quoted in Piet Beukes, The Holistic Smuts: A Study in Personality 89 (1989).

28. CRAFFord, supra note 12, at 105. 
los. After his electoral defeat to Hetzog in 1924, he resumed his interest in these ideas and in 1926 published his book entitled Holism and Evolution. ${ }^{29}$

As the title of this book indicates, Smuts' views on Holism should be seen in tandem with his views on evolution. Charles Darwin, whose room at Christ's College was not far from the one that Smuts would later occupy in the same college, had published On the Origin of Species in 1859. Darwin's ideas had a far-reaching influence on Smuts when he arrived in Cambridge decades later. Smuts rejected the mechanical explanation of the universe of many natural scientists that was standard before Darwin. According to Smuts' theory of evolution, life and mind arose in and from matter; the universe is not purely a physical mechanism that reflects the totality of its parts. Instead, in Smuts' famous phrase, "the whole . . . is more than the sum of its parts." ${ }^{\prime 30}$ There is a formal unity between all cells, atoms, and mind; they contain a creative force called Holism, the fundamental organizing force of the universe.

The insight by Einstein - with whom Smuts was in correspondence-that space and time are rooted in experience, rather than prior to it, is key to Smuts' breaking out of what he saw as the mechanist mold. In a mechanical understanding of the universe, "[l]ife is practically banished from its own domain, and its throne is occupied by a usurper. Biology thus becomes a subject province of physical science-the Kingdom of Beauty, the free artistic plastic Kingdom of the universe, is inappropriately placed under the iron rule of force." ${ }^{\prime 31}$

During a speech in the chapel of his alma mater, Christ's College, Cambridge, on 21 October 1934, Smuts said that Holism meant that, "we are not alone, not mere individual atoms alone in this world." ${ }^{32}$ This was in line with his contention that we live in a "friendly universe." ${ }^{33}$ Smuts' philosophy of Holism underlies and finds expression in his work towards establishing the Union of South Africa, the League of Nations, and the United Nations.

Another important influence on Smuts' approach was his life-long exposure to English radicalism, pacifism, and feminism. ${ }^{34}$

29. Jan Christianan Smuts, Holism and Evolution (1926).

30. From Smuts' preface to the German edition of Holism and Evolution, April 1938, quoted in P.B. Blanckenberg, The Thoughts of General Smuts 161, 164-65 (1951).

31. Smuts, Holism and Evolution, supra note 29, at 4.

32. Unpublished notes of an address by Smuts in the chapel of Christ's College, Cambridge, on Sunday 21 October 1934. In some respects Holism exhibits remarkable similarities with the concept in African humanism that sometimes finds expression in the term "Ubuntu," which emphasizes our shared humanity_ "I am because we are." For further reading material on Ubuntu, see, for example, Timothy Murithi, Practical Peacemaking Wisdom from Africa: Reflections on Ubuntu, 1 J. Pan Afr. Stud. 25 (2006).

33. Smuts, Holism and Evolution, supra note 29, at 218.

34. Schwarz, supra note 10 , at 308-319. 
Smuts was driven - by what can be viewed as both a strength and a weakness - to orientate the emerging world order along the lines of Western and Christian values as he perceived them at the time. According to Smuts, "[w]e do not want new orders. What the world wants is an older order of 2,000 years ago- the order of the Man of Galilee." ${ }^{35}$ However, he was looking for a secular manifestation of these values. In his view:

The American Declaration of Independence with its resounding affirmation of fundamental human rights, became the inspiration of the French revolution with its ideals of liberty, equality and fraternity. Thus by purely secular and worldly ways the Christian doctrine of human brotherhood had at long last won through and become the programme of the Liberal advance. ${ }^{36}$

It is probably fair to say that Smuts saw himself as someone on a civilizing mission for these values in Africa, because that was where he was born, but his primary concern was with the emerging world order as a whole. His main opponent in the battles that he fought was the militarism that emerged from Europe (British colonialism in South Africa and Prussianism and Nazism in the two world wars). He committed himself to freedom: "[i]ndividual freedom, individual independence of mind, individual participation in the difficult work of government seems to me essential to all true progress." ${ }^{\prime \prime 7}$

The Western values that he so ardently promoted, on the one hand preached love and compassion, but, on the other, reflected an often superior attitude to other races, as manifested in the dualities in the work of the philosophers he most admired, such as Kant and Hegel. This found expression in Smuts' domestic policies and practices. Smuts no doubt shared the segregationist and paternalistic views of the elites of the time. However, at the same time, he would often be caught in the vice-grip between the loftier and lower ideals of his code.

This came to the fore, for example, in his interactions with Mohandas Gandhi, who developed the model of passive resistance as a political weapon during the twenty-one years that he spent in South Africa (1893 to 1914) in opposing political and social discrimination against the Indian population group. ${ }^{38} \mathrm{~A}$ significant element in Gandhi's approach was to expose the gap between the ideals that Smuts and the South African government claimed to adhere to- and indirectly the British government—and their actual practices.

35. LeNTIN, supra note 12 , at 144 .

36. BlanCKENBERG, supra note 30, at 168-69.

37. Smuts, Jan Christian Smuts, supra note 12 , at 354.

38. Christoffel Hendrik Heyns, A Jurisprudential Analysis of Civil Disobedience in South Africa 87-95 (Oct. 1991) (unpublished Ph.D. thesis, University of Witwatersrand). 
While he was in South Africa, Gandhi's cause was strictly confined to the plight of Indians. As an example of dualism himself, Gandhi explicitly endorsed the inferior position afforded to Africans. ${ }^{39}$ However, Gandhi showed that white domination could be challenged, which fed into a more general principle of non-discrimination that would later evolve within the liberation struggle in South Africa. His method of public demonstration would find resonance in the anti-apartheid movement. Smuts later in an essay paid tribute to Gandhi, whom he said had revealed a "skeleton in our cupboard." 40

Much has been written about Smuts' approach to Africans on the one hand, and his propensity to use force on the other. While space does not permit a full exposition, some of the criticisms against Smuts' domestic policies include the following. ${ }^{41}$

In May 1921, an African separatist church called the Israelites occupied common land in an area called Bulhoek near Queenstown. A clash between approximately 500 members of the group and police resulted in the death or injury of 300 sect members. Political opponents accused Smuts, as head of the government at that time, of vacillation and indecision that prepared the ground for an eventual over-reaction.

Smuts was also accused of platskiet-politiek (shoot-down politics) when, in early 1922, the Administrator of South West Africa, over which South Africa held the mandate under the League Covenant, suppressed a rebellion of the Bondelswarts tribe with bombs and airplanes, resulting in the death of 115 tribe members, including women and children. ${ }^{42}$

Smuts was likewise criticized for his use of force on the domestic front against whites. As the Minister of Defense, he did not grant clemency to a 1914 rebel leader, Jopie Fourie, who was executed. Afrikaner nationalists held this act against Smuts to the end of his life. ${ }^{43}$ Also, in early January 1922, white mine workers went on strike, ironically because the Chamber of Mines proposed to do away with the industrial color bar, thereby lowering the wages of white workers and opening up their jobs to Africans. When violence ensued, Smuts declared martial law. Smuts personally took command and eventually suppressed the revolt with heavy casualties on both

39. See Maureen Swan, Gandhi: The South African Experience, 112-13, 133 (1985).

40. Ghandhi in South Africa: Reminiscences of his Contemporaries 63 (ed. E.S. Reddy), available at http://www.sahistory.org.za/sites/default/files/Gandhi\%20in\%20SA-Reminiscences\%20 $-\% 20 f u l l \% 20$ text.pdf.

41. For criticism of Smuts' racial views, see Schwarz, supra note 10, at 277-340; Morefield, supra note 10, at 171-200; Beukes, supra note 27, at 185-211; MAZOWER, No ENCHANTED Palace, supra note 10, at 19-20, 46-57; Bernard Friedman, Smuts: A Reappraisal 155-212 (1976); Cameron, supra note 23, at 165-66; Alan Paton, Jan Smuts-The Second Anniversary, The FORUM 4-6, 6 (Sept. 1952); Dubow, supra note 10, at 46-47, 60-66.

42. On the Bulhoek massacre and the Bondelswarts affair, see HanCOCK, SMUts: The Fields of ForCE, supra note 2, at 89-110.

43. On Jopie Fourie, see $i d$. at 88. 
sides, partially as a result of the South African military bombing the strikers' headquarters in Fordsburg from the air. ${ }^{44}$

Perhaps the main criticism of Smuts' actions on the racial front relates to the fact that, as Deputy Prime Minister in Herzog's fusion government, Smuts-after initial resistance-acquiesced in the Native Affairs Act of 1936. This legislation, among other things, disenfranchised Cape Africans who, hitherto, had the vote. ${ }^{45}$

Those who wish to defend Smuts could probably point out that he lived in a time when racial segregation was, in many ways, the way of the world. Many of his contemporaries as world leaders held stronger racial prejudices than Smuts. Moreover, his approach was very different from that the National Party, which unseated him in 1948 and ushered in the apartheid state. ${ }^{46}$ The Nationalists' approach was dogmatic; they believed that they had found the "solution." The future that they would eventually pursue lay in dividing South Africa and creating splinter states, the so-called bantustans, where the black population was supposed to live separate from "white South Africa." To Smuts, given his approach of Holism, any such policy was anathema. ${ }^{47}$ He condemned apartheid as "a crazy concept, born of prejudice and fear." 48

44. On the Rand rebellion of 1922 , see id. at $62-88$.

45. CAMERON, supra note 23, at 130-31.

46. Bill Schwarz' source for his contention that the difference between Smuts and the apartheid state was one of degree and not of kind does not appear to support him. Schwarz relies in his assessment on an exchange of letters in September 1949 between Smuts and one K. Howard-Browne, vice-chairman of a local branch of Smuts' United Party. Howard-Browne criticized Smuts for his "condemnation of apartheid," which, in the former's opinion, was segregation, and "a most desirable and real thing." Howard-Browne noted with regret that Smuts, "a great leader and international figure of whom we are exceedingly proud," has "ridiculed the advisability of apartheid for South Africa." K. Howard-Browne to Smuts 14 Sept. 1949, in Selections from the Smuts Papers, Volume VII, supra note 19, at 309-10. In response, Smuts stated that "up to a point," apartheid was "common ground and the traditional policy of South Africa." "Socially and residentially" it had "always been accepted South African policy." However, Smuts continued:

"[t] he Nationalist party are ... today proceeding far beyond that policy. Even the old segregation policy of General Hertzog is being abandoned, and the constitutional guarantees for the rights of the Natives and Coloured are now being set aside . . . A wild campaign is going on which must cause resentment by the non-Europeans, and may in the end lead to coloured nationalism and a common front against the white man."

Smuts to K. Howard-Browne 26 Sept. 1949, id. at 310-11.

47. Speaking against the introduction of an industrial color bar in parliament in 1925, Smuts said: "[w]e are going to declare to the Natives: 'You shall in future be debarred from rising above the level of hewers of wood and drawers of water.' I am all for the white man, but there is something in my breast that cannot stand this." Hancock, SMUTs: THE FiELDS OF FORCE, supra note 2, at 209. In fact, the apartheid Minister of Native Affairs (and Prime Minister from 1958-1966), Hendrik Verwoerd, would in 1953 state in so many words in Parliament that "[t] here is no place for [the native] in the European community above the level of certain forms of labour." Verwoerd Speaks: SpeEches 1948-1966, at 83 (A.N. Pelzer ed., 1966).

48. As quoted in Ronald Hyam, South Africa, Cambridge, and Commonwealth History 90 Round TABLE 401, 408 (2010). Keith Hancock notes that during the time of the elections:

In speech after speech in and outside parliament he [Smuts] insisted that South Africa was a unitary and dynamic economy within which white and black South Africans had no option but to work 
From this perspective, it could be added that, towards the end of his career, Smuts warned that segregation had not worked, ${ }^{49}$ that apartheid was not going to work, ${ }^{50}$ and-as he emphasized in his speech at the opening of the Voortrekker Monument in 1949, the year before he died-that a way had to be found to accommodate black aspirations within the framework of Western and Christian values. ${ }^{51}$

Perhaps the most salient point is the fact that Smuts was dependent on the white voters for his political power. Without their support back home, he would have been unable to play a role on the world stage, which is where his real interest lay. He steered close to the wind, regained power from the white electorate on the ticket of taking the country to war against Hitler with a mere thirteen votes in Parliament in 1939, and shortly after he played a leading role in the war against Hitler and in the formation of the UN, he was voted out of power back home two years before he died. His more liberal racial policies were not in accordance with those of his powerbase.

Grand apartheid and the concomitant struggle for liberation in South Africa - the Defiance Campaign, Sharpeville, Umkhonto we Sizwe-all came after Smuts' death in 1950. Until that time, not even the African National Congress ("ANC") seriously challenged segregation per se (as opposed to resisting individual repressive measures). In 1943, the African National Congress for the first time adopted a document calling for universal franchise.

And yet, from the current perspective, these arguments should not be given too much weight. South Africa's racial policies have become emblematic of centuries of wrongdoing, and Smuts remained in the first place a South African, even if he strutted the world stage. His failure to take concrete action regarding the matter of race at home remains inexcusable, especially given his remarkable abilities. The great evolutionist and visionary did not even engage in discussions with those African leaders—such as D.D.T. Jabavu, Z.K. Matthews, and many others-whom he may have regarded as "cultivated" enough. The failure to make this connection is epitomized in his refusal to meet with A.B. Xuma, the president of the African National Congress, when the latter asked to meet with him about the implications of the Atlantic Charter for South Africa. ${ }^{52}$ This is what Richard Steyn memorably calls the "hole at the heart" of Smuts' Holism. ${ }^{53}$

together: "we need them," he said, "and they need us." He warned his fellow citizens against the propaganda of fear: if they preached the black peril, the Natives would soon start preaching the white peril. Hope, not fear, he declared, was the proper attitude of mind.

Hancock, Smuts: The Fields of Force, supra note 2, at 490.

49. SCHWARZ, supra note 10, at 296.

50. See Ghandi in South Africa, supra note 40.

51. J.C. Smuts, Speech (1949), in Selections from the Smuts Papers, Volume VII, supra note 19, at 332 .

52. See Heyns, The Preamble of the United Nations, supra note 11, at 347.

53. SteYN, supra note 12 , at 248 . 


\section{SMUTS' CONTRIBUTION TO THE COVENANT OF THE LEAGUE OF NATIONS $^{54}$}

As the First World War was drawing to a close and while Smuts was serving in David Lloyd George's War Cabinet, "a passion, the greatest, most poignant, most persistent of his life, was growing in [Smuts]"- the ideal of a League of Nations..$^{55}$ The President of the United States, Woodrow Wilson, had first mooted the idea and Smuts took it further. It was while convalescing from influenza at 102 Banbury Road in Oxford, the home of his Quaker friends, Margaret and Arthur Gillett, that Smuts finalized "at white heat" his pamphlet entitled The League of Nations: A Practical Suggestion on 16 December 1918.

In twenty-one propositions, amplified by paragraphs of explanation and comment, A Practical Suggestion elucidated the practicability of, and laid out a constitutional scheme for, a League of Nations. ${ }^{57}$ Lloyd George lauded Smuts' tract as "the ablest state paper he had seen during the war." ${ }^{58}$

One commentator refers to the "profound"59 influence of Smuts" pamphlet on Wilson; another states that Wilson was "captivated"60 by it; and, yet a third, that Wilson completely "fell under [its] spell." ${ }^{61}$ Smuts' phrase, "Europe is being liquidated, and the league of nations must be the heir to this great estate," ${ }^{62}$ would in particular "thrill and inspire" Wilson. ${ }^{63}$

In his work on international organizations, Swords into Plowshares, Inis Claude Jr. states that Smuts, Woodrow Wilson, and Lord Robert Cecil deserve the title "Fathers of the League." ${ }^{\prime 4}$

54. For a detailed account of Smuts' contribution to the Covenant of the League of Nations, particularly through his pamphlet, see The League of Nations: A Practical Suggestion, and for an account of its influence on President Woodrow Wilson, see Willem Hendrick Gravett "To Save Succeeding Generations from the Scourge of War:" International Organisation and Human Rights 105-252 (2015) (unpublished LLD thesis, University of Pretoria).

55. Millin, General Smuts, Volume II, supra note 12, at 83.

56. HancoCk, Smuts: The FieldS of Force, supra note 2, at 429.

57. Curry, supra note 10, at 969-70.

58. Lloyd George to Lord Riddell as quoted in CRAFFord, supra note 12, at 158.

59. David Hunter Miller, The Drafting of the Covenant, Volume I 34 (1928).

60. Lentin, supra note 12, at 58; see also I.C. Smith, J.C. Smuts' Role in the Establishment of the League of Nations and the Mandate for S.W.A., 5 South Afr. Hist. J. 94, 97-98 (1973).

61. Curry, supra note 10, at 975; see also Mark Mazower, Governing the World: The History OF AN IDEA 134 (2012).

62. J.C. Smuts, The League of Nations: A Practical Suggestion 8 (1919).

63. LeNTIN, supra note 12 , at 54 .

64. Inis L. Claude, Jr., Swords into Plowshares: The Problems and Progress of International OrgaNIZATION 43 (1971). 


\section{THE PREAMBLE TO THE CHARTER OF THE UNITED NATIONS}

There was a growing consciousness during the Second World War of the value of human rights and their relationship to world peace. ${ }^{65}$ President Franklin Roosevelt gave early expression to this awareness during his Four Freedoms speech in Congress in January 1941: "[f]reedom means the supremacy of human rights everywhere. Our support goes to those who struggle to gain those rights and keep them." ${ }^{\prime 66}$ Eight months later, Roosevelt and Churchill signed the Atlantic Charter. The Charter did not refer to "human rights" eo nomine, but it expressed respect for "the right of all peoples to choose the form of government under which they will live" and the hope that everyone "may live out their lives in freedom from want and fear." ${ }^{67}$ In South Africa, the Atlantic Charter would in 1943 to 1945 lead to the acceptance of a document called "Africans' claims in South Africa." For the first time the ANC called for universal franchise and direct representation of Africans in Parliament. ${ }^{68}$

The Atlantic Charter also served as the basis for the Declaration of the United Nations in January 1942, in which twenty-six countries (subsequently, forty-six) proclaimed their belief that complete victory over Hitler was essential "to defend life, liberty, independence and religious freedom and to preserve human rights and justice in their own lands as well as in other lands." ${ }^{69}$ It was the first time that the protection of human rights was stated explicitly as an Allied peace aim. As the war drew to a close, the decision was taken to establish a new international organization to succeed where the League could not, that is, to prevent such a catastrophe from recurring. This new body would place a general prohibition on the use of force by states and introduce an elaborate system of collective security, with unilateral action only in exceptional cases.

The original proposals that emanated from the Dumbarton Oaks discussions, in which Smuts was not directly involved, made scant reference to "human rights." ${ }^{70}$ These proposals did not articulate the values on which the

65. Paul Gordon Lauren, First Principles of Racial Equality: History and the Politics of Diplomacy of Human Rights Provisions in the United Nations Charter, 5 Hum. RTs. Q. 1, 4 (1983).

66. Roosevelt as quoted in id.

67. Joint Declaration of the President of the United States and the Prime Minster of Great Britain (Atlantic Charter), 14 Aug. 1941, U.S. Dep'T. St. Bull. 16 Aug. 1941, at 125, 204 L.N.T.S. 384 reprinted in The United Nations System and Its Predecessors, Volume 1, Doc. 1 (Hans von Mangoldt \& Volker Rittberger eds., 1997).

68. See From Protest to Challenge: A documentary History of African Politics in South Africa 1882-1964 Vol 2, at 209 (Thomas Karis \& Gwendolen Carter eds., 1973).

69. Joint Declaration by United Nations, 1 Jan. 1942, U.S. Dep'T. Sт. Butl. 3 Jan. 1942, at 3, reprinted in The United Nations System and its Predecessors, Volume 1, supra note 67.

70. The only reference to "human rights" appeared as the promotion of "human rights and fundamental freedoms" in Chapter IX of the Dumbarton Oaks proposals, which dealt with the establishment of the Economic and Social Council, available at http://www2. mnhs.org/library/findaids/00202/pdfa/00202-00009-3.pdf. 
new world body would be based, but merely set out the structures it would create to prevent future wars.

On the eve of the San Francisco conference at which the United Nations was to be established, Smuts, now nearing the end of his career, at a meeting of Dominion prime ministers in London in April 1945, downplayed the role of legalism in international affairs. According to the minutes of the meeting, Smuts considered the proposed text of the Charter drafted at Dumbarton Oaks to be:

[A] legalistic document which did not fit the bill. We had been engaged upon one of the greatest struggles of all history. Fundamental human rights had been at stake. Like all great wars, this war had been at bottom a religious one. What the world expect from us was a statement of our human faith of the things which we had fought for and which we should try to stabilise and preserve in the world.

[Smuts] suggested that we should write into the Charter an entirely new first Chapter, which would state our human faith in the ideas for which we had fought and which we considered basic. Something like that would appeal to the world. Something was required which would touch the heart of the common man, and would make him feel that he had fought to set up not simply a piece of political machinery, but something very great. ${ }^{71}$

Smuts, therefore, drafted a proposal for a Preamble to the Charter that would be an "eloquent declaration of humanity's hopes and faith."72 Smuts proposed to the Dominion prime ministers the insertion of, inter alia, the following provisions:

1. We declare our faith in basic human rights, in the sacredness, essential worth and integrity of the human personality, and affirm our resolve to establish and maintain social and legal sanctions for safeguarding the same.

2. We believe in the practice of tolerance, in the equal rights of individuals and of individual nations large and small, as well as in their inherent right to govern themselves without outside interference, in accordance with their own customs and way of life.

3. We believe in the enlargement of freedom and the promotion of social progress, and in raising the standards of life, so that there may be freedom of thought and expression and religion, as well as freedom from want and fear for all.

4. We believe in nations living in peace and peaceful intercourse with each other as good neighbours, and in renouncing war as an instrument of national policy. ${ }^{73}$

71. Minutes of Meetings and Memoranda, British Commonwealth Meeting Apr. 1945, BCM (45) 1st-12th meetings [hereinafter Minutes]; Minutes 5th meeting, 6 Apr. 1945, at 11; see also Minutes 10th meeting, 11 Apr. 1945, at 11.

72. Hancock, Smuts: The Fields of Force, supra note 2, at 432; see generally Robert C. Hilderbrand, Dumbarton Oaks: The Origins of the United Nations and the Search for Postwar Security (1990); Ruth B. Russell, A History of the United Nations Charter: The Role of the United States 1940-1945 (1958).

73. Minutes 5th Meeting, supra note 71 , at 11. 
"The Dominion leaders greeted his suggestions with enthusiasm," under the direction of Charles Webster, an earlier discarded document of the British Foreign Office was merged with that of Smuts. It was this version that went forward to San Francisco as the South African proposal that would be supported by the United Kingdom and the other Dominions. According to Webster and Prime Minister Attlee, Smuts defined the essence and spirit of the Preamble.

The United Nations Conference on International Organization, tasked with setting up the new world body, opened in San Francisco on 25 April 1945. Mackenzie King, the Prime Minister of Canada, suggested in the Steering Committee that, since Smuts had a "standing in the diplomatic world unrivalled by any" and since many people were anxious to hear him, he should address the delegates early during the Plenary Session. Anthony Eden, British Foreign Secretary, in support of the suggestion, referred to Smuts as "the doyen of the Conference-quite unrivalled in intellectual attributes and unsurpassed in experience and authority." ${ }^{\prime 75}$ This gave Smuts the opportunity to present his plan for the preamble. In addressing the Plenary Session on 1 May 1945, Smuts stated:

The New Charter should not be a mere legalistic document for the prevention of war. I would suggest that the Charter should contain at its very outset and in its preamble, a declaration of human rights and of the common faith which has sustained the Allied peoples in their bitter and prolonged struggle for the vindication of those rights and that faith. This war has not been an ordinary war of the old type .... In the deepest sense it has been a war of religion perhaps more so than any other war of history. We have fought for justice and decency and for the fundamental freedoms and rights of man, which are basic to human advancement and progress and peace. Let us, in this new Charter of humanity, give expression to this faith in us, and thus proclaim to the world and to posterity, that this was not a mere brute struggle of force between the nations but that for us, behind the mortal struggle, was the moral struggle, was the vision of the ideal, the faith in justice and the resolve to vindicate the fundamental rights of man, and on that basis to found a better, freer world for the future. ${ }^{76}$

During discussions in Commission I on 14 June 1945, the President of the Commission described the Preamble as "the basis of the ideology of the International Organization being built." ${ }^{\prime 77}$

74. Dubow, supra note 10, at 55.

75. King \& Eden as quoted in Smuts, Jan Christian Smuts, supra note 12, at 383.

76. Documents of the United Nations Conference on International Organization San Francisco, 1945, Volume I 425 (1945).

77. The President of the Commission added that it was "one of the most interesting and most fruitful contributions that have been made to the world Charter." See UNICO Documents, Vol. VI, Doc 1123 I/8, 15 June 1945, at 2. 
The significance of the words "human rights," which did not appear in the Covenant of the League of Nations, is signaled by their central positioning in the second paragraph of the final version of the Preamble. In contrast to the Dumbarton Oakes proposals, the concept of "human rights" now constituted a central theme throughout the Charter. The words "human rights" "gain[ed] weight through repetition and context" - there were no less than seven references to "human rights" added in the body of the Charter-following their inclusion in the Preamble. ${ }^{78}$ Article 56 provides that: "[a]ll members pledge themselves to take joint and separate action in co-operation with the Organization for the achievement of the purposes set forth in Article 55" —and Article 55(c) lists "observance of, human rights and fundamental freedoms for all without distinction as to race, sex, language, or religion" as such a goal. This emphasis would become a key to the binding authority of the human rights regime upon states that ratify the Charter and thus become members of the United Nations. The passage in the Preamble to the Charter holding that the peoples of the United Nations were determined "to reaffirm faith in fundamental human rights, in the dignity and worth of the human person," is either quoted, paraphrased, or referred to in nearly all post-war human rights instruments. ${ }^{79}$

78. Dubow, supra note 10 , at 54 .

79. Christopher McCrudden, Human Dignity and Judicial Interpretation of Human Rights, 19 Eur. J. INT'L L. 655 (2008). See also Charles R. Beitz, Human Dignity in the Theory of Human Rights: Nothing But a Phrase?, 41 PHIL.. \& Pub. Aff. 259, 265 (2013). Specifically, references to this passage can be found in the following core international (including regional) human rights instruments: Universal Declaration of Human Rights, adopted 10 Dec. 1948, G.A. Res. 217A (III), U.N. GAOR, 3d Sess., arts. 1, 22, 23, U.N. Doc. A/ RES/3/217A (1948); International Convention on the Elimination of All Forms of Racial Discrimination, adopted 21 Dec. 1965, G.A. Res. 2106 (XX), U.N. GAOR, 20th Sess., pmbl., 660 U.N.T.S. 195 (entered into force 4 Jan. 1969), reprinted in 5 I.L.M. 352 (1966); International Covenant on Economic, Social and Cultural Rights, adopted 16 Dec. 1966, G.A. Res. 2200 (XXI), U.N. GAOR, 21st Sess., pmbl., arts. 5(2), 13(1), U.N. Doc. A/6316 (1966), 993 U.N.T.S. 3 (entered into force 3 Jan. 1976); Convention on the Elimination of All Forms of Discrimination Against Women, adopted 18 Dec. 1979, G.A. Res. 34/180, U.N. GAOR, 34th Sess., pmbl., U.N. Doc. A/34/46 (1980), 1249 U.N.T.S. 13 (entered into force 3 Sept. 1981); Convention Against Torture and Other Cruel, Inhuman or Degrading Treatment or Punishment, adopted 10 Dec. 1984, G.A. Res. 39/46, U.N. GAOR, 39th Sess., pmbl., U.N. Doc. A/39/51 (1985), 1465 U.N.T.S. 85 (entered into force 26 June 1987); Convention on the Rights of the Child, adopted 20 Nov. 1989, G.A. Res. 44/25, U.N. GAOR, 44th Sess., pmbl, arts. 23(1), 28(2), 37(c), 39, 40(1), U.N. Doc. A/44/49 (1989), 1577 U.N.T.S. 3 (entered into force 2 Sept. 1990); Declaration on the Protection of All Persons from Enforced Disappearance, adopted 18 Dec. 1992, G.A. Res. 47/133, U.N. GAOR, 47th Sess., pmbl., arts. 19(2), 24(5)(c), U.N. Doc. A/RES/47/133 (1992); Convention on the Rights of Persons with Disabilities, adopted 13 Dec. 2006, G.A. Res. 61/106, U.N. GAOR, 61th Sess., pmbl., arts. 1, 3(a), 8(a), 16(4), 24(a), 25(d)), U.N. Doc. A/RES/61/106 (2006) (entered into force 3 May 2008); Optional Protocol to the International Covenant on Economic, Social and Cultural Rights, adopted 10 Dec. 2008, G.A. Res. 63/117, U.N. GAOR, 63rd Sess., pmbl., U.N. Doc. A/RES/63/117 (2008); Second Optional Protocol to the International Covenant on Civil and Political Rights, aiming at the abolition of the death penalty, adopted 15 Dec. 1989, G.A. Res. 44/128, U.N. GAOR, 44th Sess., pmbl., U.N. Doc. A/44/49 (1989) 
The final version of the Preamble contained several amendments from the one initially presented by Smuts at the meeting of Dominion prime ministers. Most of the text of the Preamble derives from the draft of Smuts, but an editing exercise by an American delegate and the Dean of Barnard College, Virginia Gildersleeve, was responsible for substituting the phrase "dignity and worth of the human person" for Smuts" phrase "sanctity and ultimate value of human personality." ${ }^{\prime 80}$

Strikingly, while Smuts' text provided that human rights should be enforced through sanctions, the element of sanctions or effective protection-the essence of the modern concept of human rights-was omitted from the final version. We will return to this puzzle below.

The differences and similarities between the three main stages of the development of the Preamble, specifically with reference to the phrases "human rights" and "human personality," are set forth in the following table:

Smuts' role in putting human rights on the international agenda should not be exaggerated. Smuts was not alone in advocating for the inclusion of human rights in the Charter. From the outset of the San Francisco Conference in April of 1945, the dearth of human rights provisions in the Dumbarton Oaks Proposals was a contentious public issue. A number of civil society proposals for human rights provisions emerged, ${ }^{81}$ and found strong support

(entered into force July 11, 1991); Optional Protocol to the Convention against Torture and other Cruel, Inhuman or Degrading Treatment or Punishment, adopted 18 Dec. 2002, G.A. Res. A/RES/57/199, U.N. GAOR, 57th Sess., pmbl., reprinted in 42 I.L.M. 26 (2003); American Convention on Human Rights, signed 22 Nov. 1969, pmbl., arts. 5(2), 6(2), 11(1), O.A.S. Doc. OEA/Ser.L/V/II.23, doc. 21, rev. 6 (1979), O.A.S.T.S. No. 36, 1144 U.N.T.S. 143 (entered into force 18 July 1978); African Charter on Human and Peoples' Rights, adopted 27 June 1981, pmbl., art. 5, O.A.U. Doc. CAB/LEG/67/3 Rev. 5, 1520 U.N.T.S. 217 (entered into force 21 Oct. 1986); European Convention on Human Rights, opened for signature 4 Nov. 1950, pmbl., 213 U.N.T.S. 221, Europ. T.S. No. 5 (entered into force 3 Sept. 1953); Protocol No. 13 to the Convention for the Protection of Human Rights and Fundamental Freedoms, opened for signature 5 May 2002, Eur. T.S. 187, (2003) (entered into force 7 Jan. 2003); Charter of Fundamental Rights of the European Union, DO C 364/01, 18 Dec. 2000, pmbl., arts. 1, 25, 31(1) (2000).

80. Beitz, supra note 79, at 266. Gildersleeve initially proposed the phrase "to reaffirm faith in the dignity and value of every human being" as a substitute for Smuts' first two clauses, "to re-establish faith in fundamental human rights, in the sanctity and ultimate value of human personality." However, here Beitz is incorrect, the drafting committee did not accept Gildersleeve's proposal in toto. Smuts' "faith in fundamental rights" remained, and Gildersleeve's "dignity and worth of every human being" replaced Smuts' "sanctity and ultimate value of human personality" only. Aside from altering "value" to "worth" and Smuts' change of "human being" to "human person," the delegates did not make any other significant changes to this part of the Preamble. See Samuel Moyn, Why is Dignity in the Charter of the United Nations?, Humanity (10 June 2014).

81. For example, during this time W.E.B. Du Bois directed a campaign of the National Association for the Advancement of Colored People to force the new United Nations to fulfil the promises of the Atlantic Charter for self-determination, Morn, The LASt Utopia, supra note 6 , at 60-61. 
Smuts Proposal at Meeting of Dominion Prime Ministers (6 April 1945)

1. We declare our faith in basic human rights, in the sacredness, essential worth and integrity of the human personality, and affirm our resolve to establish and maintain social and legal sanctions for safeguarding the same.
Final Submission by SA Delegation in San Francisco (3 May 1945)

... to re-establish faith in fundamental human rights, in the sanctity and ultimate value of human personality, in the equal rights of men and women and of nations large and small ... .
Preamble of the Charter as adopted

(26 June 1945)

... to reaffirm faith in fundamental human rights, in the dignity and worth of the human person, in the equal rights of men and women and of nations large and small ...

among non-European states, especially those of Latin America. ${ }^{82}$ And, the inclusion of human rights in the Charter, important as it was, evolved only later into the modern concept of human rights with a fully-fledged enforcement system developed.

In this context, it is telling to consider how limited Smuts' notion of human rights really was.

\section{SMUTS' CONCEPT OF "HUMAN RIGHTS"}

From the perspective of the present, Smuts' conception of human rights can at best be described as rudimentary. Yet, at the time it broke new ground.

\section{A. Human Rights as a Reaction to war}

It appears from the above that Smuts' concept of human rights was rooted in his experience of the horrors of war-the First and Second World War and the most devastating of colonial wars, the South African War. ${ }^{83}$ One of the themes of Smuts' justification for his participation in these armed

82. See Katarina Månsson, Reviving the "Spirit of San Francisco": The Lost Proposals on Human Rights, Justice and International Law to the UN Charter, 76 NORD. J. INT'L L. 217, 217 (2007).

83. See Martiı Koskenniemi, The Gentle Civilizer of Nations: The Rise and Fall of International Law 1870-1960 120 (2002). It should be borne in mind that by the time Smuts used the phrase "human rights," he had been integrally involved in, and had helped to end, three of the most devastating military conflicts in human history. Smuts experienced firsthand human suffering on a scale almost unimaginable to anyone living in a developed country today. Upon his arrival in San Francisco Smuts had told reporters: "[o]ur race has reached the limit of human endurance ..." Heyns, The Preamble of the United Nations Charter, supra note 11, at 337. 
conflicts was resistance against the outdated approach of what he called "militarism," epitomized for him first in British and then in German aggression. He expressed this resistance in philosophical terms as the opposition of "the will to power," in the phrase appropriated from Nietzsche, against the Kantian approach, which he favored, that individuals should not be used as a means to an end. ${ }^{84}$ However, unlike others who reacted to war, such as Henry Dunant, the founder of the International Committee of the Red Cross, who focused on making war more human, Smuts' principal interest was in preventing war from occurring in the first place. Smuts' approach can perhaps be described as a manifestation of the Kantian idea of jus post bellum, or justice after war, aimed at establishing perpetual peace through the creation of a "cosmopolitan federation." 85

As Dubow argues, in Smuts' mind, "[h] uman rights concerned basic or minimal needs like security and life, and they pertained to matters like freedom of expression or religion." 86 It seems fair to assume that Smuts saw human rights as short-hand for those values, the violation of which had led to the wars in which he had seen such carnage and devastation. He had witnessed unimaginable destruction mostly between European states engaged in international armed conflict; that is what he set himself out to stop. ${ }^{87}$ In a very real sense, Smuts had the opportunity to rectify a shortcoming of the League of Nations by placing the quest for world peace by the United Nations on a firmer footing; one that addressed the causes of war. Human rights were in that sense at best a secondary concern for Smuts-his first concern was world peace. But in doing so his aim was very specific - the problem he wanted to solve was confined to the destructive tendency in Western societies towards war.

Today, historians, such as Moyn, question the extent of the knowledge of the delegates at San Francisco about the Nazi death-camps, and, as a result, also whether the international human rights order was, in fact, primarily a reaction to the horrors of the Second World War. ${ }^{88}$ In this context it becomes important to ask what Smuts knew.

84. J.C. Smuts, Message to South Wales: Speech delivered at Tonypandy, Rhondda (29 Oct. 1917).

You want the human individual not to be merely a means to an end, you do not want the human individual to be exploited, you do not want individuals for self-aggrandizement, but you want them to develop and reach the highest that they are capable of reaching. That you can only gain by attain by relying on the principle of liberty.

[T] he German system ... [is] not liberty, not freedom, not righteousness. The will to power is the ideal that dominates the German system . . .

85. Brian Orend, The Morality of War 20 (2006) (internal quotation marks omitted).

86. Dubow, supra note 10, at 70.

87. Mazower, No Enchanted Palace, supra note 10, at 60-61.

88. See Jan Herman Burgers, The Road to San Francisco: The Revival of the Human Rights Idea in the Twentieth Century, 14 Hum. Rts. Q. 447, 475 (1992); Morn, The Last Utopia, supra note 6 , at 6 . 
According to the journalist David Friedmann, on the afternoon of 3 May 1945-the day Smuts submitted to the San Francisco Conference the South African proposal for the Preamble-Smuts explained what he meant with the phrase "fundamental human rights." According to Friedmann, Smuts said that he was in possession of detailed and confirmed accounts of the appalling atrocities committed at Auschwitz, Bergen-Belsen, Treblinka, Dachau, and other Nazi camps. He also had received a full report of the gross violations of the Geneva Convention governing the treatment of prisoners of war who had been forced into slave labor, starved to death, and summarily shot. It was in the context of these crimes, Smuts said, that he wanted the United Nations to "re-establish faith in fundamental human rights." 89

However, his concept of human rights did not expand much beyond that. The examples he cited and the wars in which he participated largely entailed atrocities by Europeans committed against Europeans. It therefore seems reasonable to deduct that Smuts' motivation may have been his desire for Europeans to live up to what he considered to be their normative system in their treatment of one another. It is abundantly clear, however, and Smuts emphatically stated, that he did not believe that human rights were synonymous with political or racial equality. In defending the Union's policies against the attack launched by India during the first meeting of the General Assembly in 1946, Smuts argued that South Africa had not violated any fundamental human rights within the terms of the Charter since, at that time, there was no internationally recognized formulation of fundamental rights. ${ }^{90}$

Smuts' legacy as an internationalist is as the "visionary, globe-trotting statesman-philosopher, committed to his evolutionist paradigm of cosmic harmony." ${ }^{\prime 91}$ The thrust of Smuts' ideas, words, and actions was to secure the freedom of the world from Bolshevism, Fascism, and later Communism-a good number of the alternative utopias that Moyn argues the human rights utopia was designed to counter. ${ }^{92}$ He was not, in the first place, concerned with individual freedom.

Smuts expressed himself against an emphasis on "individualistic rights," which "give no recognition to that organic human and social unity which the duties of the older codes recognized as the real rule and law and pattern of right living." ${ }^{93}$ Smuts stated to the Confucian Chung-Shu Lo: ${ }^{94}$ "there is the

89. The Humanist Imperative in South Africa 128 (John W. De Gruchy ed., 2011).

90. Hancock, Smuts: The Fields of Force, supra note 2, at 469.

91. Mazower, No Enchanted Palace, supra note 10, at 57.

92. See note 22 above.

93. Dubow, supra note 10, at 66 (internal quotation marks omitted). The older codes he had in mind were those of Hammurabi, the Ten Commandments, and the Sermon on the Mount.

94. Chung-Shu Lo was a university professor from China, and "one of the philosophers consulted by UNESCO in 1947 on the question of the universality of human rights." Id. at 65 . 
right to live, to self-development, to self-expression, and to enjoyment . . . . our modern emphasis on 'rights' [is] somewhat overdone and misleading." ${ }^{95}$ Smuts, in all likelihood, would have agreed with his one-time adversary, "Gandhi, who disliked rights-talk of all kinds, associating it with the selfindulgence of the modern age." ${ }^{\prime 96}$

The three wars in which Smuts played a major role resulted in slaughter in the context of armed conflict between states. It is probable that his primary concern was the maltreatment perpetrated by governments, not against their own populations, but against the populations of other states. The prevailing idea was that only states could be subjects and thus holders of rights under international law and that only states were entitled to the protection of the international community. The general acknowledgment of the idea that individuals, too, were subjects of international law was a later development.

Also in line with this approach was the idea that state sovereignty about what happens inside their borders should prevail against the United Nations. At San Francisco, Smuts lobbied with the other Dominion delegates, most notably the Australians, for the adoption of Article 2(7) of the Charter that holds that the United Nations may not interfere in the domestic affairs of member states. ${ }^{97}$

Human rights to Smuts were certainly not a utopia. Dag Hammarskjöld (Secretary-General 1953 to 1961) famously said that "[t] he United Nations was not created to take mankind to heaven, but to save humanity from hell." 98 "Hell," in the eyes of Smuts, was the specter of another world war, possibly even more devastating than the ones he had lived through. For Smuts, first and foremost, human rights were a means to prevent a third world war. It seems fair to say that Smuts was not primarily interested in rights. He rather saw them as a means to achieve what was more important to him, i.e., peace and a stable international environment in which South Africa could play a role.

Smuts clearly did not foresee how rapidly and extensively, and, in many ways, how differently from his vision, human rights would evolve to attempt to address the needs of an era to which he did not belong.

95. Smuts to Chung-Shu Lo 29 July 1947, in Selections from the Smuts Papers, Volume VII, supra note 19 , at 155 .

96. Dubow, supra note 10, at 68 (internal quotation marks omitted).

97. Lorna Lloyd, "A Most Auspicious Beginning": The 1946 United Nations General Assembly and the Question of the Treatment of Indians in South Africa, 16 Rev. INT'L Stud. 131, 131 (1990).

98. As quoted in "To Save Humanity": What Matters Most for a Healthy Future xxii (Julio Frenk \& Steven J. Hoffman eds., 2015). 


\section{B. Human Rights, Duties, and Holism}

From the above, it is clear that Smuts' conception of "freedom" was not synonymous with political equality. Smuts did not consider freedom to be an inalienable right, entitlement, or demand, but, rather, something that had to be earned. The language of "duty" was an intrinsic part of Smuts' understanding of rights. Smuts held that the expression of rights in the traditions of Rousseau, the French Revolution, and the American Declaration of Independence, allowed people to forget that "the other and more important side of 'right' is 'duty.' And indeed the great historic codes of our human advance emphasized duties and not rights." 99 The "great historic codes" he referred to are those of Hammurabi, the Roman Twelve Tables, the Ten Commandments, and the Sermon on the Mount.

The draft of the Preamble as presented by Smuts at San Francisco pledged "[t]o re-establish faith in fundamental human rights, in the sanctity and ultimate value of human personality." "Human personality" became "human person" in the final document. ${ }^{100}$ Smuts' use of the word "personality" was not happenstance; the word had particular significance and was fundamental to his Idea of the Whole (recalling his dissertation as a student at Cambridge on Walt Whitman). For Smuts, the human personality was the "highest whole": "[t]o be a free Personality represents the highest achievement of which any human being is capable.... and to realise wholeness or freedom (they are correlative expressions) ... not only represents the highest of which the individual is capable, but expresses also what is at once the deepest and the highest in the universal movement of Holism." 101

It was through the process of completing the personality that the achievement of freedom depended; for Smuts, "human rights, like human Personality, were both conditioned and conditional."102 Smuts' concept of "personality" made differential degrees of freedom and differential treatment of groups by the state not merely reasonable but necessary for human progress. ${ }^{103}$ More-

99. Smuts to Chung-Shu Lo 29 July 1947, in Selections from the Smuts Papers, Volume VII, supra note 19 , at, 155 .

100. Heyns, The Preamble of the United Nations Charter, supra note 11, at 341.

101. Smuts, Holism and Evolution, supra note 29, at 312. Millin, General Smuts, Volume II, supra note 12 , at 408 . Arguing that Human personality is at the pinnacle of the progressive series of wholes in the evolution of the present universe; human personality is the supreme achievement of life. Beukes, supra note 27, at 128. Commenting on a review of Bertrand Russell's History of Philosophy, Smuts rejected the doctrine of analyzing experience into its ultimate elements (sense data): "[u]nless the holistic factor is introduced into this analytical situation you are left with the raw crude elements. How can you reverence the human personality - and give it the status which it occupies in the preamble of the Charter, if personality is but sense-data and sensibilia?" Smuts to M.C. Gillett 6 Feb. 1947, in Selections from the Smuts Papers, Volume VII, supra note 19, at 123.

102. Dubow, supra note 10, at 58.

103. Mazower, No Enchanted Palace, supra note 10, at 64. 
over, Smuts' conception of "human rights," like "Holism," was evolutionary: something that was forged in and grew through struggle. ${ }^{104}$

It may be concluded from the above that a range of factors contributed towards Smuts being able to introduce the term "human rights" into the Charter. First, at San Francisco he was seen as a trusted military figure and an international statesman with a long record of fighting against military aggression and who was making a proposal about preventing future wars in the death throes of a devastating conflict. More problematically, he could play this role only on the basis that he was the premier of his country. And lastly, it is our contention that the fact that the concept of "human rights" was not given a clear content at the time, but was understood to be limited in reach, also allowed it to be presented by Smuts and to be accepted by the other states. From that point of view, its very vagueness was a virtue.

States did not sign a blank check in San Francisco by adopting the Charter as far as the meaning and content of human rights were concerned. In many respects it was left open for later determination, also by those states that were not major powers at the time, including those which were in the process of decolonization. These unintended consequences of the process that he initiated Smuts would soon enough see in action for himself.

\section{SMUTS ACCUSED OF HUMAN RIGHTS VIOLATIONS IN THE GENERAL ASSEMBLY}

Smuts attended the first meeting of the General Assembly of the United Nations in New York in October 1946 and, relying on his country's favorable wartime reputation, requested the incorporation of what was then known as South West Africa into the Union. According to Hancock, Smuts could probably have annexed the territory with impunity. ${ }^{105}$ However, some commentators see his presence at the United Nations as an act of deference to the international system. ${ }^{106}$ In any event, the tide would now turn dramatically against him.

At India's insistence, the General Assembly rejected incorporation by thirty-seven votes to nine. ${ }^{107}$ Moreover, at an earlier plenary meeting during the same session, the Indian delegation quoted the words Smuts was

104. See, for example, Heyns, The Preamble of the United Nations Charter, supra note 11, at 337. It is noteworthy that Smuts, in reaction to Gandhi's campaign of civil disobedience to advance the cause of the Indian population of South Africa, requested Gandhi to prepare, in Smuts' words, a "bill of rights." Heyns, A Jurisprudential Analysis of Civil Disobedience in South Africa, supra note 38, at 101.

105. Hancock, Smuts: The Fields of Force, supra note 2, at 467.

106. See LeNTIN, supra note 12 , at 147.

107. U.N. GAOR, 4th Comm., 1st Sess., Plenary Sess., at 1323 (1946). 
responsible for introducing into the Charter- "human rights"—against him in reproach for the South African government's policies with respect to the treatment of the Indian population in South Africa. ${ }^{108}$ Ms. Pandit, on behalf of the Indian delegation, contended that justice was essentially nondiscriminatory, and that by this standard, South Africa's racial policies were indefensible and in violation of the United Nations foundational standards. ${ }^{109}$

Smuts did not have any good (or even bad) political argument in response. He pinned almost his whole case upon the argument that the legislation in question belonged essentially to South Africa's domestic jurisdiction. If peace were to be preserved in the world, Smuts argued, the fundamental principle was the one laid down in Article 2(7) of the Charter, namely, that there should not be interference in the domestic jurisdiction of any state. ${ }^{110}$ Smuts had been responsible for introducing the phrase "human rights" into the language and politics of the United Nations; now he was the first person to be branded by that institution as a human rights violator. ${ }^{111}$ Ironically, given Smuts' emphasis on purpose rather than law, he implemented a legal defense that set the precedent for succeeding generations of South African diplomats at the UN, who would invoke state sovereignty with a similar lack of success.

This development was of great symbolic importance in the evolution of the United Nations and was the precursor to a long series of actions against the South African government for racial discrimination in general in the world forum. ${ }^{112}$ Much of the emerging new international human rights system would develop precisely in response to the policies of the South African government. Mazower describes the vote against South Africa as "the first act of assertion by the colonial world against the principles of racial hierarchy and European rule." ${ }^{113}$ Smuts was the first casualty of the new system that he had helped to create, and he admitted sardonically that he was exposed as a "hypocrite."114

108. U.N. GAOR, 1st \& 6th Comm., 1st Sess., Plenary Sess., at 1046 (1946).

109. Id.

110. Id. at 1042 .

111. Hancock, Smuts: The Fields of Force, supra note 2, at 469. There was a precursor to this sequence of events when South Africa was taken to task by the Permanent Mandates Commission of the League of Nations for its aerial bombardment of the Bonderlzwaarts rebels in South West Africa over which South African held a mandate. In that case, also, Smuts was responsible for setting the international standard and subsequently was viewed as a perpetrator in terms of the same rules. See Mazower, No Enchanted Palace, supra note 10, at 51.

112. R.B. Ballinger, UN Action on Human Rights in South Africa, in The International ProtectION Of Human Rights 248, 251-52 (Evan Luard ed., 1967).

113. Mazower, No Enchanted Palace, supra note 10, at 26.

114. Smuts to M.C. Gillett 27 Nov. 1946, in Selections from the Smuts Papers, Volume VII, supra note 19 , at 110 . 
It was clear that the new world organization would not confine itself to the restricted vision of its founders. The human rights provisions of the Charter would acquire a life of their own. A space would thus be created for states to criticize each other and for civil society not only to play into that dynamic, but also to develop into a supra-national movement. ${ }^{115}$

It is worth emphasizing the subsequent role of the developing world also in establishing other parts of the human rights project as we know it today. The continuing strong Western influence in human rights (and other areas of international law) cannot and should not be denied. However, Roland Burke has argued forcefully that the arrival of newly independent states of Asia, Africa, and the Middle East in the UN General Assembly transformed the human rights program of the UN in significant ways. ${ }^{116}$ Likewise, from the current perspective, the future of human rights will also depend on the extent to which communities outside the main stream will participate in its development.

In a roundabout and unintended way, the inclusion of human rights in the Charter would serve as an important cog in the machine that would eventually reverse South Africa's domestic racial policies, which Smuts felt he would leave to others to resolve.

\section{CONCLUSION}

As in the case with his role in apartheid, the challenge lies in neither understating nor overstating Smuts' contribution to human rights. Neither human rights nor racial segregation was his primary concern-his guiding star was to establish a stable world order based on his understanding of that which was worth preserving and entrenching in Western values.

Smuts' real contribution to human rights, in our view, is three-fold.

In the first place, drawing on his years of experience as a military leader and an international statesman, he was the person inside the system who drove the process to found the new world body on human rights principles. This was no spur of the moment intervention prompted by idealistic emotion or that of a randomly selected scribe who was tasked with reducing what others were saying into writing. Smuts used his stature and record as a soldier, statesman, and a founder of the League of Nations to first convince the British and Commonwealth leaders in London, and then the founding states of the United Nations in San Francisco, that the new world body should be founded on the basis of human rights. At the same time, he probably did not understand the full consequences of doing this.

115. See Mazower, No Enchanted Palace, supra note 10, at 152.

116. Roland Burke, Decolonization and the Evolution of International Human Rights (2010). 
In the second place, Smuts insisted on the fundamental connection between human rights and peace in the manner in which the UN would pursue world peace. This connection remains a central component of the approach of the United Nations to world peace and human rights during the last seventy years.

In the third place, and once again probably inadvertently, Smuts played a central role in making a commitment to human rights binding law on all states. Once the Preamble was adopted, all other formal amendments in the Charter relating to human rights followed. ${ }^{117}$ Subsequently, the Charter came to mention "human rights" no less than seven times, ${ }^{118}$ and the phrase thus became part and parcel of the treaty that every nation had to accept in order to become part of the world body.

Acceptance of human rights as a legal obligation thus became a precondition for membership of the international community. The Charter would become the primary legal foundation of the international human rights project. In short, Smuts served a central role in turning human rights from a noble aspiration into binding law. Complying with human rights norms would henceforth be a legal obligation on states and a standard against which they could be measured by an ever-expanding formal and informal system of accountability.

At the outset of this article it was argued that the historiography of human rights has largely excised the role of Smuts-mainly on the understandable basis of his domestic policy. However, a consequence of leaving such a gap in the storyline may have contributed to an approach that sees the history of human rights as largely discontinuous and, consequently, its long-term effects as transient. Smuts is not "the missing link" that proves the evolutionary origin of human rights, but we propose that a better understanding of Smuts' role supports an evolutionary understanding of the origins and historical rootedness of human rights.

The Western influence at the origin of the human rights project is confirmed by the above account of Smuts' role. Yet it is remarkable how soon human rights started to acquire a life of its own, as evidenced by Smuts' exit from the United Nations, and indeed from the history books. The many others, with their own interests and experiences, who have subsequently contributed to the international human rights system have helped to give it a more cosmopolitan and, in some respects, universalist character. True universality not only means the same values apply to all, but that there is universal participation in determining those values. The project to make

117. See Jeremy Brown Shearar, Against the World: South Africa and Human Rights at the United Nations 1945-1961 (unpublished LLD thesis, University of South Africa, 2007).

118. In addition to the Preamble, "human rights" are mentioned in U.N. Charter arts. 1(3), 13(1)(b), 55(c), 62(2), 68, 76(c), signed 26 June 1945, 59 Stat. 1031, T.S. No. 993, 3 Bevans 1153 (entered into force 24 Oct. 1945). 
human rights more inclusive will have to be continued if the concept is to remain relevant.

A number of general conclusions may be added.

There is ample evidence of a deep duality in the international order, as exemplified by the history some of its main architects, of which Smuts is but one example. ${ }^{19}$ Woodrow Wilson is another. ${ }^{120}$ They often go back and forth between the general good and their own narrow self-interest, or that of their group. Moreover, states follow the same pattern. Prominent founding member states of the United Nations chose to emphasize human rights in the formal instruments of that body yet openly tried to maintain their worldwide colonial empires, as was the case with some countries in Europe, or those who practiced legalized racial discrimination domestically, as with the United States. On the regional level, the European Convention on Human Rights was adopted with the colonial empires of the member states of the Council of Europe fully intact. In time, acceptance of the ideals expressed in the Convention would render such practices untenable. ${ }^{121}$ The human rights project, given its dualistic character, does not represent an objective order and is not neutral; like law in general, international law represents a nexus of power relations and value judgments. At best, it is a fusion of the self-interest of its creators and a measure of idealism. International law, including human rights law, should thus never be seen as fully objective or even trustworthy - it always represent interests. Smuts' duality is a particularly visible manifestation of the duality of the international system itself. Though this duality should be understood, this does not mean it has to be accepted.

Because human rights evolve through struggle, as a product of evolutionary change, its advancement often depends on exposure of the space afforded by duality, for example, when a state commits to a new value system without fully thinking through the consequences of the commitment.

Inclusion of the term "human rights" in the Preamble of the UN Charter, albeit with limited ambitions, afforded the opportunity that allowed further progress. Dualism has a considerably less menacing undertone when it means that the old and the new are represented in a transitionary figure-someone who forms a bridge between the old and the new and stands with one foot in the past and another in the future. To a large extent, the human rights movement has evolved-and continues to evolve-because of a tension between the universal and parochial values, i.e., dualism in action.

119. Psychologists refer to this phenomenon as moral compartmentalization. Steven Pinker, The Better Angels of Our Nature: Why Violence Has Declined 658 (2011).

120. Regarding Wilson's troublesome legacy as both a liberal internationalist and a racial segregationist, see Andy Newman, At Princeton, Woodrow Wilson, a Heralded Alum, is Recast as an Intolerable One, N.Y. Times (22 Nov. 2015), https://www.nytimes. com/2015/11/23/nyregion/at-princeton-addressing-a-racist-legacy-and-seeking-toremove-woodrow-wilsons-name.html?_r $=0$.

121. Christof Heyns, African Human Rights Law and the European Convention, 11 South Afr. J. Hum. RTs. L. 252, 254 (1995). 
The account of Smuts' role in the evolution of human rights may be employed to describe a pattern in the history of human rights-we may call it the "problem-principle-problem" pattern: a protagonist (or protagonists) confront a specific problem, primarily pursuing their self-interest, they seek to legitimize their actions by invoking a general principle as the motivation, but the generality of the principle may open up shortcomings on their own side which they did not anticipate. The implementation of the emerging principle exposes the duality, and potentially_if they do nothing about it-the hypocrisy of the authors: they do not meet the standards they had set and become the recipients of the process they initiated. The dialectical process continues, and, in turn, each claimant is exposed.

Importantly, however, it is precisely because those who advance the original general principle have an interest in the acceptance of that principle that it has any chance of adoption and survival. The fact that it is based on interest is both the strength and weakness of human rights. Human rights are not lofty ideals to be plucked from the air, but norms that evolve in an evolutionary fashion from below.

A clear example of the problem-principle-problem dynamic occurs when someone fights against racial oppression and invokes the value of non-discrimination, only to be confronted later with the fact that this also militates against discrimination on other grounds - grounds that the person in question had at the time not yet considered or was not ready to accept, such as discrimination based on gender or sexual orientation. Through the repetition of the problem-principle-problem pattern, narrow self-interest is transformed and enlarged.

In short, human rights are often used in an instrumentalist way that have unintended consequences for their authors.

Smuts saw war and aggression among Western powers as being in conflict with the true values of this culture. In order to address this problem he invoked the principle of human rights. The full reach of the principle that Smuts invoked was made applicable to his domestic policy and would play a significant role in the undoing of those who took the levers of power from him.

In the case of Gandhi, we saw that he initially focused on the plight of Indians in South Africa and supported the subservient role of Africans. To promote his cause, he invoked the principle of non-discrimination, which made his earlier position vis-a-vis Africans untenable.

What is also clear is that future generations may question many of our current practices, which to us seem to be the "way of the world" - our treatment of the environment comes to mind-and ask how it was possible that their predecessors who were in some ways so enlightened were in others so short-sighted. 
Many questions remain. For example, did Smuts, who firmly believed that the onerous terms of the Treaty of Versailles were going to lead to another world war, want to remain in a position to play a leading role when it happened, and politics as the art of the possible determined that he should not alienate the only people who could secure a power base to do that-the white voters at home. It is difficult to tell, but if that was his motivation his plans certainly worked out with the slimmest of margins. He narrowly won the vote to lead the country into war against Nazism in 1939, and he was unceremoniously booted out in the first election after the war, inter alia, because he was seen to be too soft on race. Those particularly sympathetic to Smuts may even ask whether the inclusion of human rights in the UN Charter was a roundabout way of addressing the racial problems at home that he could not resolve during his time in power.

It seems, however, that what can be said is that even if a more nuanced approach is taken to Smuts' involvement in both racial segregation and human rights, as we have suggested above, a chasm remains. His dualism is pronounced and visible. It is by seeing it for what it is that a better understanding of the fault line that runs through international law and relations, and indeed probably the human personality, and human rights, can be gained. Nothing is innocent; the self-interests of those who devise even the most high-minded systems invariably play a central role.

It is in this tension field that any ambitions for "a better world" have to play themselves out. The human rights project-like international law in general-even if it reflects higher aspirations, is constrained by the limitations of those individuals who drive it. But that is not where the story ends. If Smuts' tale and the subsequent evolution of the human rights project is anything to go by, the eventual product can also be more than the sum of its flawed, if sometimes brilliant, parts. 